\title{
A revision and phylogenetic analysis of the millipede genus Oxidus Cook, 1911 (Polydesmida, Paradoxosomatidae)
}

\author{
Anh D. NGUYEN ${ }^{1, *}$, Zoltán KORSÓS ${ }^{2}$, Kuem-Hee JANG ${ }^{3}$ \& Ui-Wook HWANG ${ }^{4}$ \\ ${ }^{1,3,4}$ Institute of Phylogenomics and Evolution, Kyungpook National University, \\ 1005, KNU Global Plaza, 80 Daehakro, Bukgu, Deagu, 702-701, South Korea. \\ ${ }^{1}$ Institute of Ecology and Biological Resources, Vietnam Academy of Science \\ and Technology, 18, Hoangquocviet Rd., Caugiay District, Hanoi, Vietnam. \\ ${ }^{2}$ Tropical Biosphere Research Center, University of the Ryukyus, \\ Senbaru 1, Nishihara, Okinawa 903-0213, Japan. \\ ${ }^{2}$ Hungarian Natural History Museum, Baross u. 13, H-1088 Budapest, Hungary. \\ ${ }^{4}$ Department of Biology, Teachers College, Kyungpook National University, 80 \\ Daehakro, Bukgu, Deagu, 702-701, South Korea. \\ *Corresponding author: ducanh410@yahoo.com \\ ${ }^{2}$ Email: zkorsos@gmail.com \\ ${ }^{3}$ Email: goldlight@knu.ac.kr \\ ${ }^{4}$ Email: uwhwang@knu.ac.kr

\footnotetext{
${ }^{1}$ urn:lsid:zoobank.org:author:FCE53D0A-593C-4ACC-800B-E0237DC185F4

${ }^{2}$ urn:1sid:zoobank.org:author:60C5576D-D9AB-4DB2-9B5B-053E1E9EFF8E

${ }^{3}$ urn:1sid:zoobank.org:author:9734778C-89F9-488D-8376-B6842327D80A

${ }^{4}$ urn:1sid:zoobank.org:author:F32F6F6F-3F7A-48B3-AE5A-E63776A87438
}

\begin{abstract}
The genus Oxidus Cook, 1911 is revised to contain five species, O. avia (Verhoeff, 1937), O. gigas (Attems, 1953), O. gracilis (C.L. Koch, 1847), O. riukiaria (Verhoeff, 1940), and "species inquirenda" O. obtusus (Takakuwa, 1942). A cosmopolitan species, O. gracilis, is widely found in temperate and sub-tropical regions over the world, but other species have limited distribution in restricted regions, e.g., O. gigas in northern Vietnam, O. riukiaria and O. avia in the Ryukyu Islands (Japan). Four species, $O$. gracilis, $O$. riukiaria, $O$. avia and $O$. gigas, are confirmed as different from each other in gonopod characters, coloration and body size. The status of the last species, O. obtusus, is still doubtful and requires examination of further fresh material. The phylogenetic relationships among species of Oxidus is analyzed using two fragments of the mitochondrial genes COI (Cytochrome c Oxidase subunit I) and 16S rRNA. Three species of Oxidus are clearly separated from each other; O. gigas and O. gracilis form a monophyletic sister group with $O$. riukiaria. The genus Oxidus is also monophyletic and more closely related to the genus Tylopus Jeekel, 1968 than to the genera Sellanucheza Enghoff, Golovatch \& Nguyen, 2004 or Kronopolites Attems, 1914. In addition, an identification key to species of Oxidus is provided.
\end{abstract}

Keywords. Millipedes, Diplopoda, Oxidus, molecular phylogeny, revision. 
Nguyen A.D., Korsós Z., Jang K.-H. \& Hwang U.-W. 2017. A revision and phylogenetic analysis of the millipede genus Oxidus Cook, 1911 (Polydesmida, Paradoxosomatidae). European Journal of Taxonomy 293: 1-22. https:// doi.org/10.5852/ejt.2017.293

\section{Introduction}

The genus Oxidus was proposed for the species Fontaria gracilis C.L. Koch, 1847 by Cook (1911). However, Attems (1914) also proposed a subgenus, Kalorthomorpha, of the genus Orthomorpha Bollman, 1893 for the same species. Later, Kalorthomorpha was elevated to full generic rank and considered to be a junior synonym of Oxidus (Jeekel 1968).

The taxonomic history of the genus Oxidus is relatively complicated. Takakuwa (1942a, b) did not accept the genus Oxidus, and he reported ten species under the genus Orthomorpha from South Korea: Orthomorpha avia Verhoeff, 1937, O. circofera Verhoeff, 1931 (= Orthomorphella pekuensis according to Hoffman (1963)), O. circofera affinis Verhoeff, 1936 (= Orthomorphella pekuensis according to Hoffman (1963)), O. coarctata (De Sausure, 1860), O. gracilis, O. nordenskiöldi (Attems, 1909) (= Cawjeekelia nordenskioeldi according to Jeekel (1988)), O. pekuensis (Karsch, 1881) (= Orthomorphella pekuensis), O. riukiaria Verhoeff, 1940, O. cristata Takakuwa, 1942 (listed as species incertae sedis by Nguyen \& Sierwald (2013)) and O. obtusus Takakuwa, 1942. On the contrary, Chamberlin (1945) recognised the genus Oxidus from Java (Indonesia) with eight species, Oxidus sequens Chamberlin, 1945, O. lamellifer Chamberlin, 1945, O. filarius (Attems, 1932), O. pygmaeus (Pocock, 1894), O. hydrobiologicus (Attems, 1927), O. annex Chamberlin, 1945, O. malabarus Chamberlin, 1945 and O. pangrangus Chamberlin, 1945. All those species were subsequently assigned to other genera (Jeekel 1963b; Nguyen \& Sierwald 2013).

Chamberlin \& Wang (1953) referred all circofera, gracilis, pekuensis, obtusus and nordenskiöldi to the genus Oxidus. However, Takakuwa (1954) listed only four species of Oxidus, O. gracilis, O. avia, O. riukiaria and O. obtusus, for the Japanese fauna. Wang (1957) added another species, Oxidus (Varyomorpha) hsientienensis Wang, 1957 (= Nedyopus hsientienensis according to Chen et al. (2006)) from Taiwan. Miyosi (1959) considered only five species Oxidus gracilis, O. circofera, O. nordenskioeldi, $O$. cristatus and $O$. obtusus from Japan.

Jeekel (1963a, 1968) accepted the validity of the genus Oxidus, and listed only five species and subspecies, O. avia, O. gracilis, O. gracilis ssp. gigas (Attems, 1953), O. obtusus and O. riukiaria. O. gracilis gigas was poorly described as Kalorthomorpha gracilis gigas from North Vietnam (Attems 1953), and recently raised to full species rank by Enghoff et al. (2004).

O. gracilis (C.L. Koch, 1847) is a cosmopolitan species; O. obtusus (Takakuwa, 1942) was known from South Korea, both O. avia (Verhoeff, 1937) and O. riukiaria (Verhoeff, 1940) were reported from South Japan, and lastly $O$. gigas (Attems, 1953) was recoded from North Vietnam. Except for O. gracilis, all the remaining species have had no further records since their establishment. This paper seeks to answer three questions based on morphological and molecular analyses. Morphological data is used to classify species and molecular data is used to examine their phylogeny.

1) How many species are actually in the genus Oxidus?

2) What are the relationships among species of Oxidus?

3) Does the genus Oxidus form a monophyletic group with closely related groups, e.g., Tylopus and Sellanucheza? 


\section{Material and methods}

\section{Taxon sampling, identification and DNA extraction}

Examined material was collected by hand in northern Vietnam and southern Japan, or was borrowed from the collections in Kyungpook National University (KNU) (Korea) and the Hungarian Museum of Natural History (HNHM). All were examined under an Olympus SZX10 microscope with a drawing tube.

Total genomic DNA was extracted from leg tissue using the DNAeasy Blood \& Tissue Kit (Qiagen TM).

\section{DNA amplification and sequencing}

Fragments of two mitochondrial genes, cytochrome c oxidase subunit I (COI) and 16S rRNA, were amplified using polymerase chain reaction (PCR). Universal primers LCO-1490 and HCO-2918 (Folmer et al. 1994) or COI-1F20 (5'-ACT CTA CTA ATC ATA AGG AT-3') and COI-1R19 (5'-TAAACC TCC GGG TGA CCAA-3') were used to amplify a 680 bp fragment of the COI gene. Primer sets $16 \mathrm{Sa}$ (5'CGC CTG TTT AHC AAA AAC AT-3') -16Sb (5'-CCG GTY TGA ACT CAR ATC CA-3') or 16S1F19 (5'- CCG GTT TGA ACT CAG ATCA-3') and 16S-1R20 (5'-TGA CTG TTT AGC AAA GAC AT-3') were used to amplify a 550 bp fragment of the $16 \mathrm{~S}$ rRNA gene. PCR conditions for amplification of the $16 \mathrm{~S}$ rRNA gene were: an initial denaturation at $95^{\circ} \mathrm{C}$ for 2 min followed by 36 cycles of $95^{\circ} \mathrm{C}$ for $20 \mathrm{sec}, 45^{\circ} \mathrm{C}$ for $40 \mathrm{sec}$ and $72^{\circ} \mathrm{C}$ for $1 \mathrm{~min}$, and a final extension at $72^{\circ}$ for $5 \mathrm{~min}$. The PCR conditions for the amplification of COI were: initial denaturation at $94^{\circ} \mathrm{C}$ for $5 \mathrm{~min}$ followed by 38 cycles of $94^{\circ} \mathrm{C}$ for 45 seconds, $42^{\circ} \mathrm{C}$ for 45 seconds, $72^{\circ} \mathrm{C}$ for 90 seconds, and a final extension at $72^{\circ} \mathrm{C}$ for $5 \mathrm{~min}$. After thermal cycling, $2 \mu \mathrm{PCR}$ products were screened for potentially successful amplification of a fragment of $16 \mathrm{~S}$ or COI through electrophoresis in $1 \%$ agarose-TBE $1 \mathrm{X}$. The electrophoresis was performed at conditions of $100 \mathrm{~mA}$ and $120 \mathrm{~V}$ for 1 hour.

About $20 \mu 1$ of successfully amplified PCR products were purified using ExosapIT or the QIAquick PCR Purification Kit (Qiagen Inc.). Purified PCR products were sequenced at Solgen, Inc (Korea) in an Applied Biosystems automatic sequencer (ABI3130 XL) using the same primer sets used for initial PCR.

\section{Alignment and phylogenetic analysis}

Each successful sequence was manually checked using BioEdit ver. 7.1 (Hall 1999) and confirmed by BLAST searches (Altschul et al. 1990). All confirmed sequences were aligned with MUSCLE (Edgar 2004). Ambiguous nucleotide sites and gaps were removed using MEGA ver. 6.0 (Tamura et al. 2013). The reliability of the alignment was estimated using distance estimation and model of p-distance. Nucleotide frequencies were statistically calculated using MEGA 6.0. These COI sequences were translated into amino acids for confirmation using transversion code in MEGA 6.0.

Model test was implemented in MEGA 6.0 to find the most appropriate maximum likelihood substitution model for COI and 16S. Models with the lowest Bayesian Information Criterion (BIC) scores were considered for describing the best substitution pattern for each gene. Codon positions included were: $1^{\text {st }}+$ $2^{\text {nd }}+3^{\text {rd }}+$ Noncoding. The selected model for COI was the Tamura-Nei model $+\mathrm{G}+\mathrm{I}$ (Tamura $\&$ Nei 1993). For the combination of COI and 16S rRNA, the Hasegawa-Kishino-Yano model (Hasegawa et al. 1985) was used. Phylogenic trees were constructed using both maximum likelihood (ML) and Bayesian inference (BI) models. Maximum likelihood bootstrap analysis was conducted using MEGA 6.0 with 1000 replicates. A Bayesian inference (BI) tree was created using MrBayes ver. 3.1.2 (Huelsenbeck $\&$ Ronquist 2001) with 10 million generations, heating parameter of 0.06 , and sampling every 1000 generations. All nucleotide sequences were deposited at GenBank. Collection localities, specimen - 
Table 1. Details of specimens analysed for DNA, including GenBank numbers.

\begin{tabular}{|c|c|c|c|c|c|}
\hline No. & Species & Locality & Voucher & 16S rRNA & COI \\
\hline 1 & $\begin{array}{l}\text { Oxidus gigas } \\
\text { (Attems, 1953) }\end{array}$ & Sapa, Lao Cai, Vietnam & IEBR-Myr 113 & KX096912 & KX096921 \\
\hline 2 & $\begin{array}{l}\text { Oxidus gigas } \\
\text { (Attems, 1953) }\end{array}$ & $\begin{array}{l}\text { Duc Xuan, Ha Giang, } \\
\text { Vietnam }\end{array}$ & IEBR-Myr 516 & KX096917 & KX096928 \\
\hline 3 & $\begin{array}{l}\text { Oxidus riukiaria } \\
\text { (Verhoeff, 1940) }\end{array}$ & Okinawa, Japan & IEBR-H500 & KX096915 & KX096926 \\
\hline 4 & $\begin{array}{l}\text { Oxidus riukiaria } \\
\text { (Verhoeff, 1940) }\end{array}$ & Okinawa, Japan & IEBR-H500J & KX096916 & KX096927 \\
\hline 5 & $\begin{array}{l}\text { Oxidus gracilis } \\
\text { (C.L. Koch, 1847) }\end{array}$ & USA & GenBank & - & KR136012 \\
\hline 6 & $\begin{array}{l}\text { Oxidus gracilis } \\
\text { (C.L. Koch, 1847) }\end{array}$ & USA & IEBR-USA & KX096919 & KX096931 \\
\hline 7 & $\begin{array}{l}\text { Oxidus gracilis } \\
\text { (C.L. Koch, 1847) }\end{array}$ & Okinawa, Japan & $\begin{array}{l}\text { IEBR-HNHM } \\
466\end{array}$ & KX096913 & KX096924 \\
\hline 8 & $\begin{array}{l}\text { Oxidus gracilis } \\
\text { (C.L. Koch, 1847) }\end{array}$ & Okinawa, Japan & $\begin{array}{l}\text { IEBR-HNHM } \\
471\end{array}$ & KX096914 & KX096925 \\
\hline 9 & $\begin{array}{l}\text { Tylopus roseiparaterga } \\
\text { Nguyen, } 2012\end{array}$ & $\begin{array}{l}\text { Tam Dao, Vinh Phuc, } \\
\text { Vietnam }\end{array}$ & IEBR-Myr 185A & KX096909 & KX096923 \\
\hline 10 & $\begin{array}{l}\text { Tylopus crassipes } \\
\text { Golovatch, } 1984\end{array}$ & Sapa, Lao Cai, Vietnam & IEBR-Myr 92 & KX096907 & KX096920 \\
\hline 11 & $\begin{array}{l}\text { Kronopolites montanus } \\
\text { Golovatch, } 2009\end{array}$ & Pu Mat, Nghe An, Vietnam & IEBR-Myr 175 & KX096908 & KX096922 \\
\hline 12 & Kronopolites sp. & Pu Mat, Nghe An, Vietnam & IEBR-Myr 553 & KX096911 & KX096930 \\
\hline 13 & $\begin{array}{l}\text { Tonkinosoma jeekeli } \\
\text { Nguyen, } 2011\end{array}$ & $\begin{array}{l}\text { Cuc Phuong, Ninh Binh, } \\
\text { Vietnam }\end{array}$ & IEBR-Myr 545 & KX096910 & KX096929 \\
\hline 14 & $\begin{array}{l}\text { Sellanucheza grandis } \\
\text { (Golovatch, 1984) }\end{array}$ & $\begin{array}{l}\text { Huong Son, Ha Tinh, } \\
\text { Vietnam }\end{array}$ & IEBR-Myr 59 & - & KR818293 \\
\hline 15 & $\begin{array}{l}\text { Sellanucheza grandis } \\
\text { (Golovatch, 1984) }\end{array}$ & $\begin{array}{l}\text { Xuan Son, Phu Tho, } \\
\text { Vietnam }\end{array}$ & IEBR-Myr 177 & - & KR818296 \\
\hline 16 & $\begin{array}{l}\text { Sellanucheza hoffmani } \\
\text { Nguyen, } 2011\end{array}$ & $\begin{array}{l}\text { Phong Nha, Quang Binh, } \\
\text { Vietnam }\end{array}$ & IEBR-Myr 182 & - & KR818298 \\
\hline 17 & $\begin{array}{l}\text { Tonkinosoma jeekeli } \\
\text { Nguyen, } 2011\end{array}$ & $\begin{array}{l}\text { Cat Ba, Hai Phong, } \\
\text { Vietnam }\end{array}$ & IEBR-Myr 203 & - & KR818299 \\
\hline 18 & $\begin{array}{l}\text { Tonkinsoma flexipes } \\
\text { Jeekel, } 1953\end{array}$ & $\begin{array}{l}\text { Cat Ba, Hai Phong, } \\
\text { Vietnam }\end{array}$ & IEBR-Myr 207 & - & KR818300 \\
\hline
\end{tabular}

vouchers, and GenBank accession numbers are summarized in Table 1. Datasets are provided in Fasta files as supplementary data.

The COI dataset consisted of 525 bp sequences from 18 taxa. The 16S rRNA dataset included $466 \mathrm{bp}$ sequences from 13 taxa. The combination of 16S and COI genes contained 991 bp sequences from 12 taxa (Table 2). The incongruence length difference (ILD) test showed congruence of genes COI and 16S. Therefore, the analyses were performed for gene COI and the combination of $16 \mathrm{~S}$ and COI. Species of the genus Tonkinosoma Jeekel, 1953 (tribe Tonkinosomatini Jeekel, 1968) were employed as an outgroup.

\section{Abbreviations used in text and figures}

The terminology for the genus Oxidus follows that used by Likhitrakarn et al. (2010) for the genus Tylopus: 


$$
\begin{aligned}
\mathrm{ca} & =\text { cannula } \\
\mathrm{co} & =\text { coxa } \\
\mathrm{pf} & =\text { prefemorite } \\
\mathrm{fe} & =\text { femorite } \\
\mathrm{l} & =\text { postfemoral lamina } \\
\mathrm{z} & =\text { postfemoral spine } \\
\mathrm{h} & =\text { postfemoral process } \\
\mathrm{sl} & =\text { solenomere } \\
\mathrm{sph} & =\text { solenophore }
\end{aligned}
$$

\section{Institutional abbreviations}

All materials and voucher specimens are kept in:

IEBR = Institute of Ecology and Biological Resources, Hanoi, Vietnam

IPE $=$ Institute of Phylogenomics and Evolution, Daegu, Korea

KNU $=$ Kyungpook National University, Daegu, Korea

HNHM $=$ Hungarian Natural History Museum, Budapest, Hungary

\section{Results}

Order Polydesmida Leach, 1813

Family Paradoxosomatidae Daday, 1889

Tribe Sulciferini Jeekel, 1968

Genus Oxidus Cook, 1911

Oxidus Cook, 1911: 628.

Kalorthomorpha Attems, 1914: 195 (proposed as subgenus of Orthomorpha Bollman, 1893; junior objective synonym of Oxidus, see Jeekel 1968: 71).

Oxidus - Brölemann 1916: 537.

\section{Type species}

Fontaria gracilis C.L. Koch, 1847, by original designation.

\section{Diagnosis}

The genus can be distinguished from other genera in the tribe Sulciferini by the combination of characters: paraterga being well-developed; metaterga with one or two rows of setae; legs without tarsal brushes; $5^{\text {th }}$ sternum without modifications.

Gonopod relatively complicated; femorite weakly twisted, slightly or strongly enlarged distally, strongly grooved mesally, well demarcated laterally from postfemoral lamina $l$ by a distinct sulcus; solenophore with two basal processes: long, highly elevated process $h$ and short, spiniform/tuberculiform, subtransverse process $z$; solenophore twisted or strongly spiral, with mesal well-developed lobule, but without lateral lobules; solenomere flagelliform, completely sheathed by solenophore.

\section{Remarks}

This genus is distributed in the northern part of the Oriental and the eastern part of the Palearctic regions. It is unlikely that the genus is of tropical origin because it is absent from the tropical regions in the Oriental (Jeekel 1963a). Its center of origin is more likely to be Japan (Jeekel 1968). 
The genus Oxidus was placed in Sulciferini in view of the characters of the spiral solenophore completely sheathing the solenomere, the presence of a postfemoral demarcation and of postfemoral processes (Jeekel 1968). Golovatch \& Enghoff (1993) recommended that the genus should be placed relatively close to the genus Tylopus Jeekel, 1968, rather than to other sulciferinine genera. The phylogeny of the genus Oxidus is discussed below.

Oxidus gracilis (C.L. Koch, 1847)

Figs 1-2

Fontaria gracilis C.L. Koch, 1847: 142.

Fontaria gracilis - Koch C.L. 1863: 51, pl. 85, fig. 173.

Oxidus gracilis - Cook 1911: 628. — Jeekel 1963a: 20; Jeekel 1968: 71. — Nguyen \& Sierwald 2013: 1292.

Orthomorpha (Kalorthomorpha) gracilis - Attems 1914: 196.

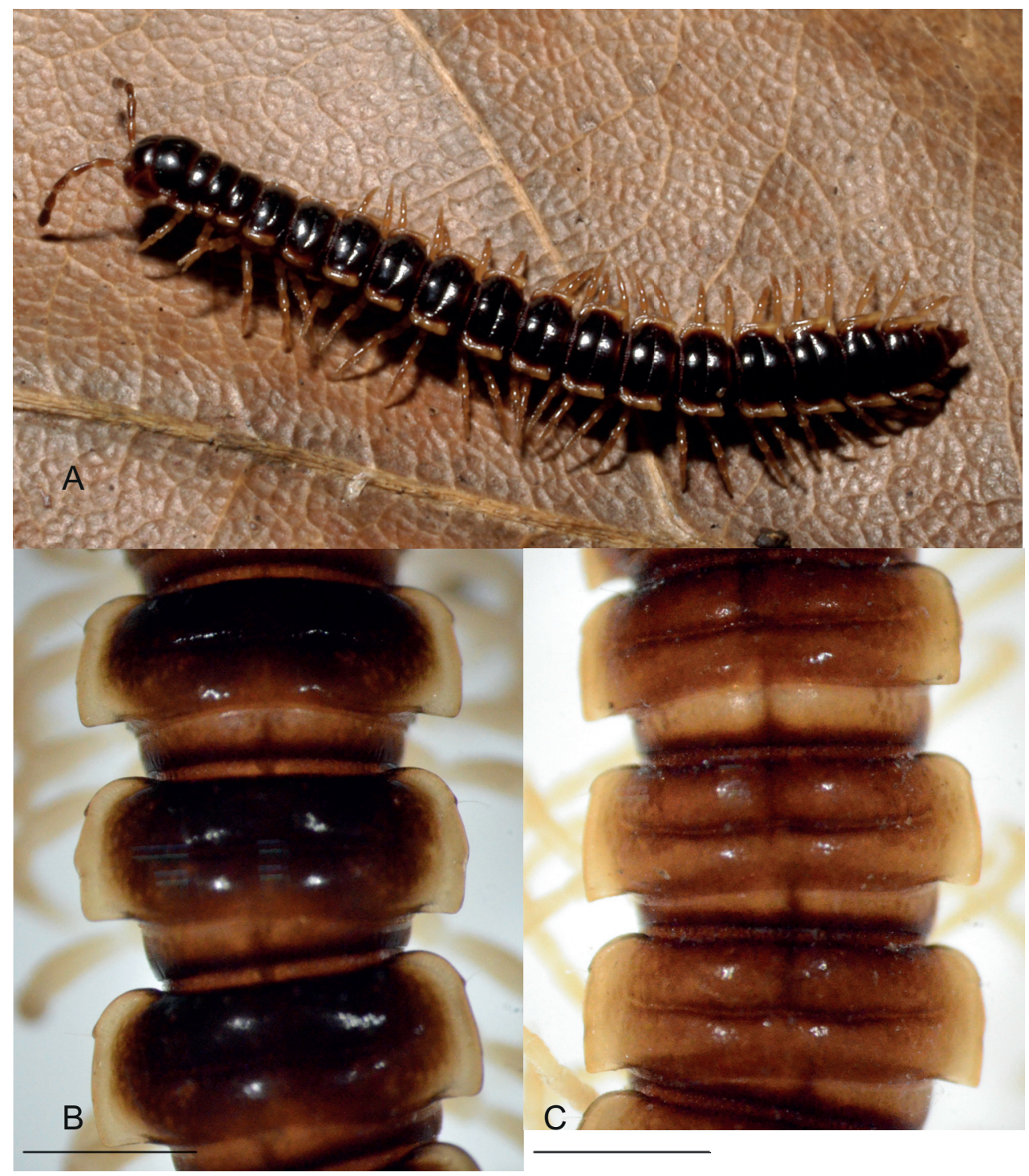

Fig. 1. Oxidus gracilis (C.L. Koch, 1847) from Okinawa Island, Japan. A. Entire body, length ca $23 \mathrm{~mm}$.

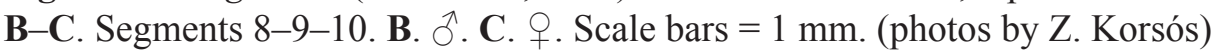




\section{Material examined}

JAPAN: $1 \delta$, Central Ryukyus, Okinawa-jima Island, Onna-son, Onna, Camp Hansen training area at

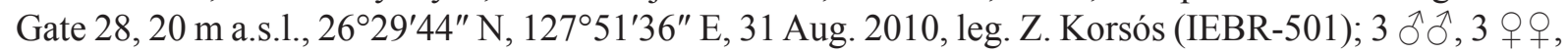
Central Ryukyus, Okinawa-jima, Okuni rindo forest trail, 26 $43^{\prime} 55^{\prime \prime}$ N, $128^{\circ} 12^{\prime} 30^{\prime \prime}$ E, 25 Sep. 2012, leg. Z. Korsós (IEBR-H471); 3 $\widehat{\jmath} \widehat{o}^{2}, 3$ 우, Central Ryukyus, Okinawa-jima, Nago city, Makiya, Makiya-notaki waterfall, $26^{\circ} 37^{\prime} 44^{\prime \prime}$ N, $128^{\circ} 02^{\prime} 42^{\prime \prime}$ E, 100 m, 2 Sep. 2012, leg. Z. Korsós (IEBR-H466).

USA: $13 \widehat{\jmath} \widehat{\partial}, 5$ 우, Florida, Columbia, Co., Ichetucknee St., PK, 3 May 1981 (IEBR-USA).

SOUTH KOREA: 4 우 (IPE-Myr 001), 1 ð̊, Geoje Island, 8 Aug. 1970, leg. K.Y. Paik (IPE-Myr 003); 7 우, Geoje Island, 7 Aug. 1970, leg. K.Y. Paik (IPE-Myr 002); 1 đૈ, Jeollanam-do, Gwangju, 6 Oct. 1962, leg. S.C.Kim (IPE-Myr 004); 4 ổ $\widehat{~}$, Songnisan National Park, 24 Jul. 1961, leg. G.Y. Baek (IPEMyr 005); 1 ڤึ, Gyeongsangbuk-do, Cheongsong-gun, Hyeondong-myeon, Wolmae-ri, 18 Jul. 1966, leg. Kim Jae Ho (IPE-Myr 007); 3 $\widehat{\partial}, 3$ q $q$, leg. K.Y. Paik (IPE-Myr 009).

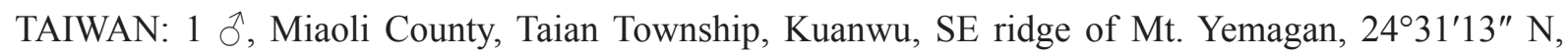
$121^{\circ} 07^{\prime} 11^{\prime \prime}$ E, $1925 \mathrm{~m}$, secondary mixed forest, 20 Oct. 2009, leg. L. Dányi and E. Lazányi (HNHM-T09-51); 1 ภ, 1 ㅇ, Taichung County, Heping Township, Dasyueshan Forest Recreation Areas, 10 Shsuehshan Rd., 7 May 2003, leg. Shining Wu (IEBR-Myr 550); 3 $\widehat{\jmath}, 1$ ㅇ, Miaoli County, Taian Township, Dalu Forest Rf., West Feeder, Guanwu lodge, 12 Aug. 2002, leg. Chen Chao Chun (IEBRMyr 551).

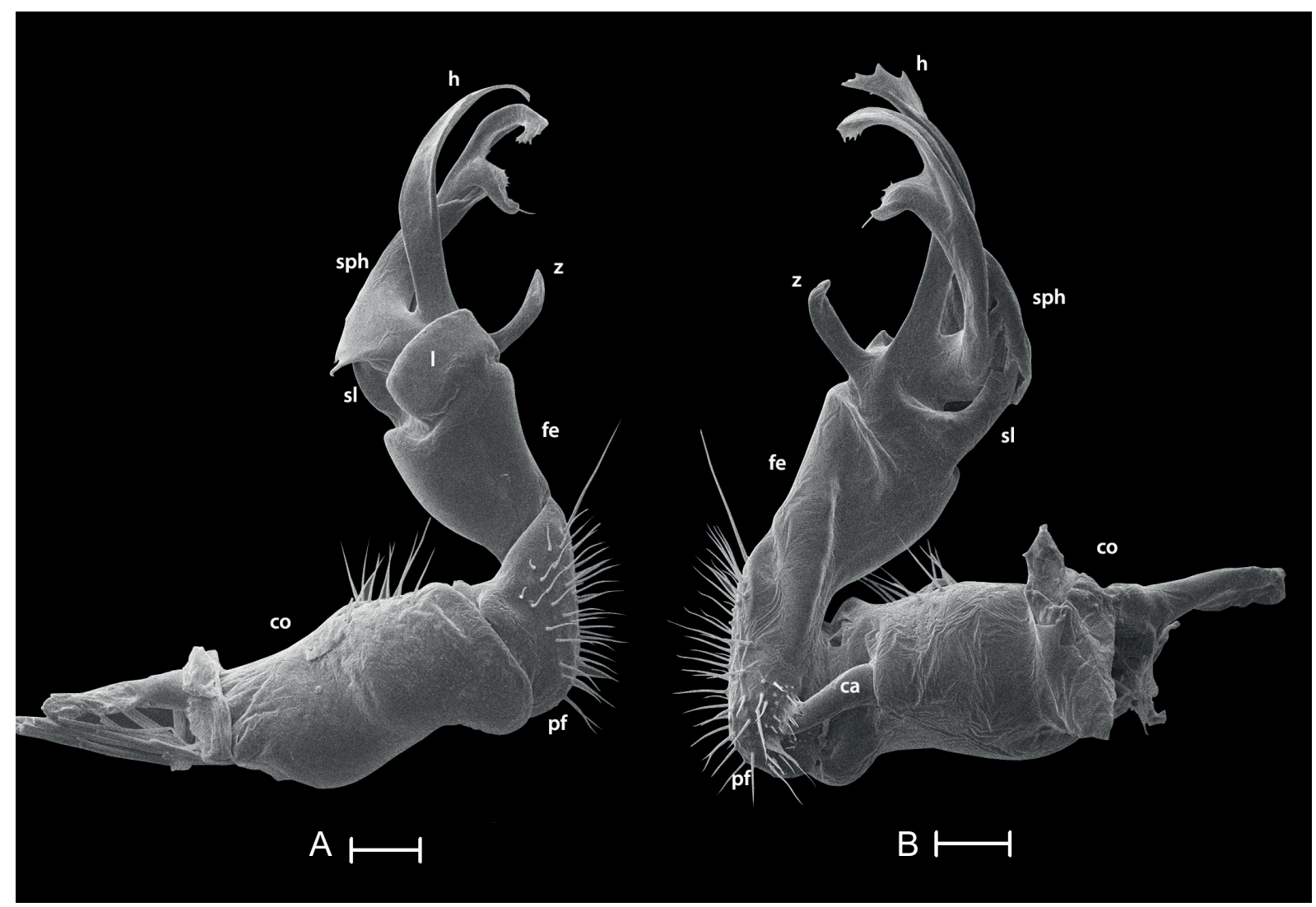

Fig. 2. Left gonopod of Oxidus gracilis (C.L. Koch, 1847), sample IEBR-USA. A. Lateral view. B. Mesal view. Scale bars $=100 \mu \mathrm{m}$. 


\section{Diagnosis}

This species differs from its congeners in the gonopod femorite being strongly expanded distally, not cylindrically slender; postfemoral lamina $l$ rectangular; spine $z$ pointed tuberculiform; process $h$ lamellar, slightly suberect, but bent upwards from midpart, serrated at distolateral part; both bases of process $h$ and spine $z$ clearly separated; mesal lobule of solenophore very well-developed, lamella-shaped, distinctly separated from tip of solenophore; tips of both mesal lobule and solenophore circularly emarginated.

\section{DNA}

For Oxidus gracilis, DNA data was collected for three genes (mitochondrial COI gene, nuclear 18S and 28S rRNA genes), but there is no data from the mitochondrial 16S rRNA. In this study, two fragments of COI and 16S were sequenced and deposited in GenBank (see Table 1).

\section{Distribution}

The species is widely distributed over the world, mainly in warm temperate regions, and associated with disturbed habitats (Nguyen \& Sierwald 2013). Island records for the Ryukyu Archipelago, Japan: Tanega-shima, Nakano-shima, Akuseki-jima, Takara-jima, Amami-O-shima, Okinoerabu-shima, Yoron-to, Okinawa-jima, Senaga-jima, Miyagi-jima, Iheya-jima, Izena-jima, Ie-jima, Kudaka-jima, Tsuken-jima, Yakabi-jima, Tokashiki-jima, Tonaki-jima, Aguni-jima, Kume-jima, Miyako-jima, Ikemajima, Ishigaki-jima, Iriomote-jima, Kohama-jima, Taketomi-jima, Aragusuku-jima, Hateruma-jima, Yonaguni-jima, Minami-Daito-jima.

\section{Oxidus gigas (Attems, 1953)}

Figs 3-4

Kalorthomorpha gracilis gigas Attems, 1953: 165, fig. 44.

Oxidus gracilis gigas - Jeekel 1963a: 20; Jeekel 1968: 60. — Golovatch 1983: 181.

Oxidus gracilis - Golovatch 1984: 54.

Oxidus gigas - Enghoff et al. 2004: 39. — Nguyen \& Sierwald 2013: 1295.

\section{Diagnosis}

This species is particularly similar to Oxidus gracilis (C.L. Koch, 1847) in body appearance and gonopod conformation, but differs in larger size and in details of gonopod structure: process $h$ narrow and long, pointed at the end and not serrated at distolateral margin; bases of process $h$ and spine $z$ less distinctly separated.

\section{Material examined}

VIETNAM: 1 đ̃, 1 \&, Lao Cai Prov., Sa Pa, Ham Rong Mts., limestone mountain, 1600 m, 16 Jul. 2006, Anh D. Nguyen, IEBR-113; 1, 6 우 (IEBR-Myr 516), 7 우 (IEBR-Myr 517), Ha Giang Prov., Bac Quang Distr., Duc Xuan Commune, Na Po village, limestone forest, under logs, 14-15 Apr. 2013, leg. Anh D. Nguyen; 1 §, 3 우, Vinh Phuc Prov., Tam Dao National Park, forest, 900-1000 m, Mar. 2012,

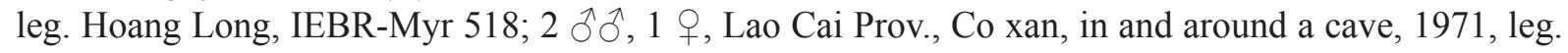
Gy. Topál \& I. Matskási, IEBR-H133.

\section{Redescription}

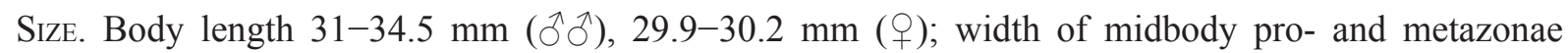

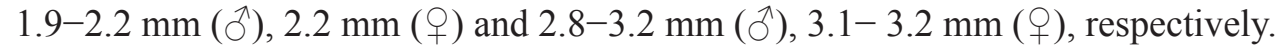


COLORATION. Generally castaneous brown, but anterior half of metaterga and posterior margin of prozonae darkish brown. Posterior half of metaterga, anterior margin of prozonae and pleura castaneous brown; paraterga, sterna and legs brownish yellow.

HEAD. Slightly narrower than collum; labrum sparsely setose; epicranial suture distinct, dividing frons into two equal parts. Antennae long and slender, not claviform, reaching segment 3 if stretched posteriorly. Antennomere $1<7<<2=3=4=5=6$ in length.

CoLLum. Subequal to, or slightly narrower than collum, trapeziform; surface shining and smooth, without rugosity; setae broken, but traces of two rows: $3+3$ close to anterior margin and $1+1$ in middle. Paraterga large, ear-shaped with broadly rounded laterocaudal corners; lateral side with a setiferous incision.

In width, segment $4 \leq 3<2<5-17$, thereafter gradually tapering towards telson. Prozonae and metaterga shining, smooth, without rugosity. Metaterga with two rows of setae: $2+2$ close to anterior margin and

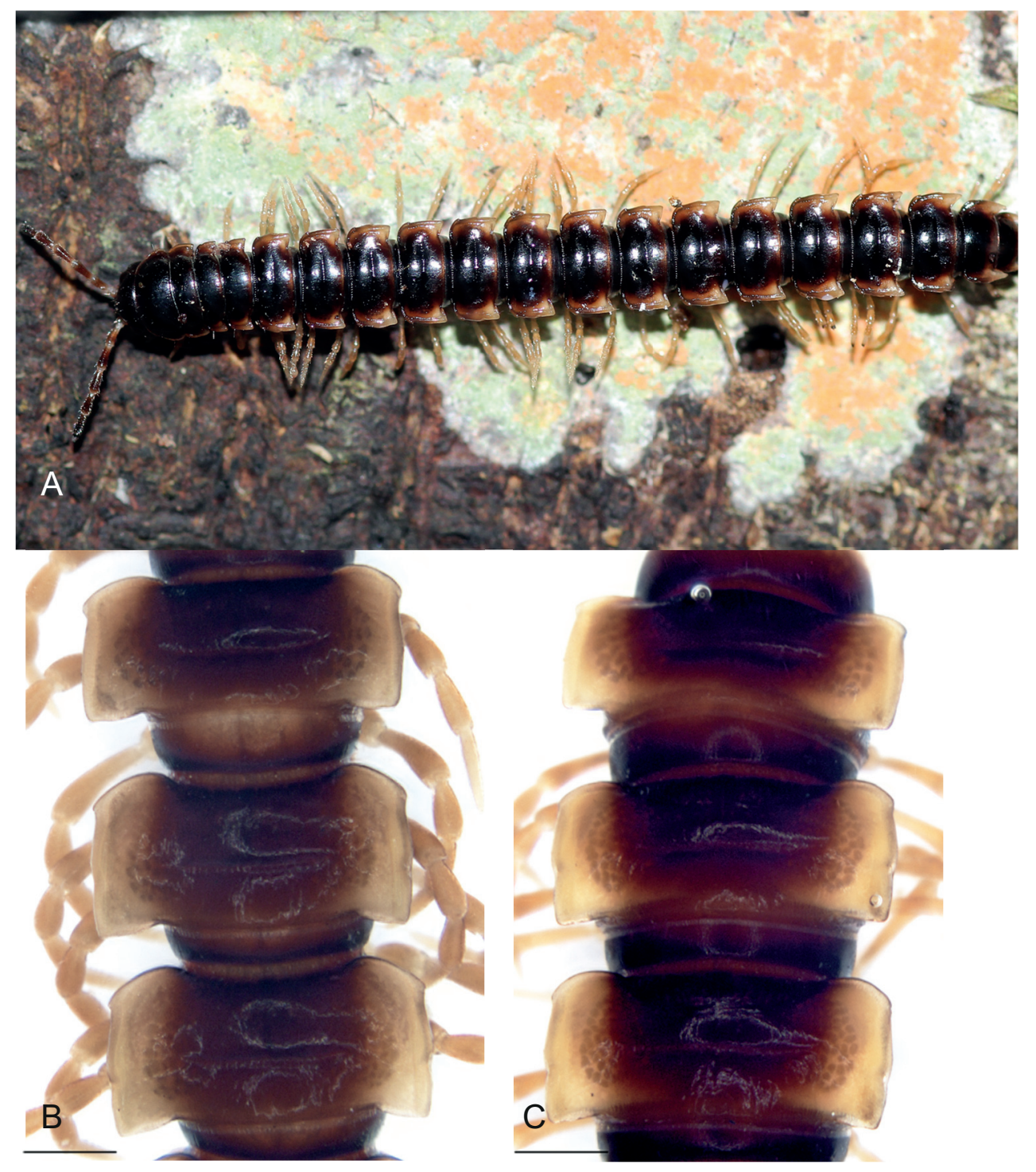

Fig. 3. Oxidus gigas (Attems, 1953) from Duc Xuan Commune, Ha Giang Prov., Vietnam. A. Entire body, length ca $34 \mathrm{~mm}$. B-C. Segments $8-9-10$. B. ${ }^{\text {O }}$. C. . . Scale bars $=1 \mathrm{~mm}$. (photo by Anh Nguyen) 
$2+2$ close to posterior margin. Transverse sulcus starting on metatergum 4, well developed, reaching base of paraterga on metaterga 5-19, beaded at bottom on some caudal segments. Stricture between pro- and metazonae clearly distinct, broad and striolate at bottom. Pleura shining, smooth; pleurosternal carinae completely absent or poorly developed only on pre-gonopodal segments.

PARATERga. Well developed, lying subequal to or lower than metatergal surface. Calluses small, but obvious; lateral side with 2 setiferous incisions at $1 / 3$ and $2 / 3$ of its length. Anterior corner broadly rounded, but posterior corner acute, produced into a pointed projection on segments 15-17. Ozopores located behind second lateral incision of paraterga 5, 7, 9, 10, 12, 13, 15-19.

Eрiproct. Long, but broadly truncated, dorsoventrally flattened, with two minute apical tubercles. Tip with four spinnerets. Hypoproct trapeziform, with two well separated, distolateral, setiferous knobs.

STERnA. Modestly setose, without modifications, but with a minute cone caudally near each coxa.

LEG. Long and slender, about 1.6-1.7 (ð), 1.4-1.5 (ㅇ) times as long as midbody height. Tarsal brushes absent. Prefemora not swollen. Femora without modifications.

GoNOPOD. Relatively complicated. Coxite cylindrical, long, subequal to femorite in length; distoventral part sparsely setose. Prefemorite densely setose, separated laterally from femorite by a distinct oblique sulcus. Femorite weakly twisted, grooved mesally, more or less slightly enlarged distally, without modifications and demarcated from postfemoral region by a lateral sulcus. Postfemoral region shorter than femorite, with a lateral sub-pentagonal lamina l; spine $\mathrm{z}$ pointed; process $\mathrm{h}$ long and pointed, not serrated laterally; bases of process $\mathrm{h}$ and spine $\mathrm{z}$ not separated. Solenophore strongly spiral; distomesal lobule well developed and distinctly separated from solenophore tip. Solenomere flagelliform, completely sheathed by solenophore.

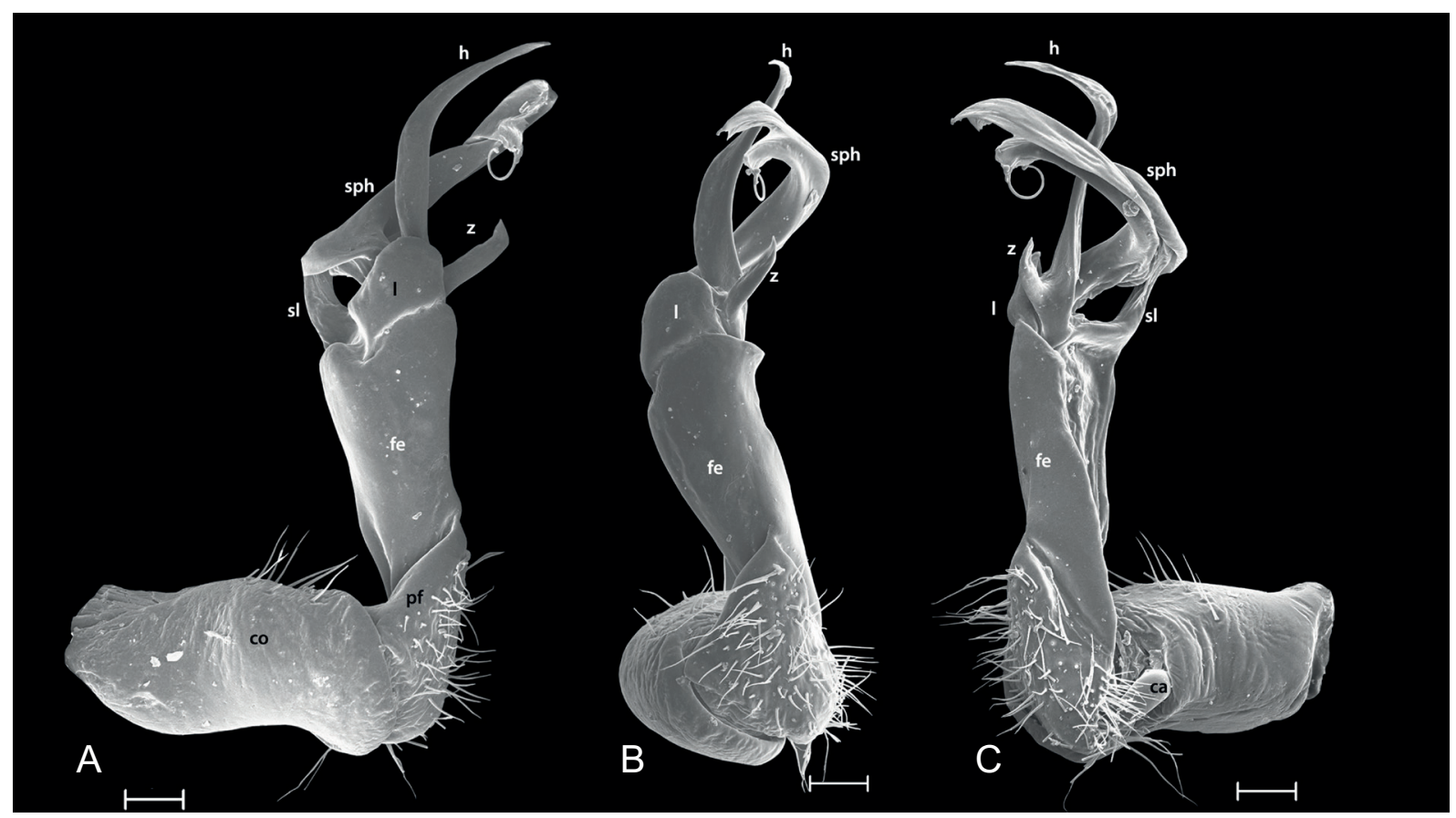

Fig. 4. Right gonopod of Oxidus gigas (Attems, 1953), from sample IEBR-Myr 113. A. Lateral view. B. Ventral view. C. Mesal view. The picture has been flipped horizontally. Scale bars $=1 \mathrm{um}$. 


\section{DNA}

COI and 16S barcode data (partial) are deposited in GenBank (Table 1).

\section{Habitats}

All material was found under leaf-litter, logs and decaying wood.

\section{Distribution}

The species has only been recorded from northern Vietnam (Lao Cai, Ha Giang and Vinh Phuc Provinces).

\section{Remarks}

Attems (1953) proposed a new subspecies Kalorthomorpha gracilis gigas with a short note. Enghoff et al. (2004) raised this subspecies to full rank as Oxidus gracilis, and also showed minor differences in size and gonopod process $\mathrm{h}$. The species is fairly similar to $O$. gracilis, but the molecular data has provided strong evidence to separate the species.

Golovatch (1984) misidentified O. gracilis in Vietnam (sample IEBR-H133), which is currently corrected as $O$. gigas in this paper.

Oxidus riukiaria (Verhoeff, 1940)

Figs 5-7

Orthomorpha riukiaria Verhoeff, 1940: 139, figs 5-6.

Orthomorpha riukiaria - Takakuwa 1954: 39, fig. 34.

Oxidus riukiarius - Jeekel 1963a: 20.

Oxidus riukiaria - Nguyen \& Sierwald 2013: 1295.

\section{Material examined}

JAPAN: 4 के $\hat{0}, 4$ qq, Central Ryukyus, Okinawa-jima, Ogimi village, Nerome, above road no.58,

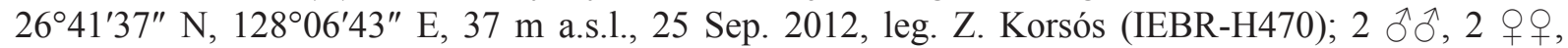
Okinawa-jima, Yanbaru, Ogimi village, Nunha, Okuni rindo, 26 $41^{\prime} 10.1^{\prime \prime} \mathrm{N}, 128^{\circ} 09^{\prime} 02.7^{\prime \prime}$ E, 15 Sep. 2012, leg. Nakamura Y. (IEBR-H500); $2 \overbrace{}^{\Uparrow}$, Central Ryukyus, Okinawa Island, Yanbaru, Kunigami village, Cape Hedo, Ginama, broad-leaved evergreen forest, 176 m, 26 ${ }^{\circ} 49^{\prime} 52^{\prime \prime}$ N, $128^{\circ} 16^{\prime} 20^{\prime \prime}$ E, 5 Apr. 2011, leg. Z. Korsós (HNHM-355); 1 đै, Northern Ryukyus, Tokara group, Kuchino-shima Island, around Kuroshio-so guesthouse, 2959'24" N, 12955'21" E, 63 m, 14 Oct. 2012, leg. Z. Korsós (HNHM-477).

Other records (newly found ones underlined)

JAPAN: Northern Ryukyus, Tokara Group: Kuchino-shima Island; Central Ryukyus: Okinawa-jima, Kume-jima, Iheya-jima, Aguni-jima, Zamami-jima, Aka-jima, Geruma-jima (observations by Z. Korsós).

\section{Diagnosis}

Oxidus riukiaria can be distinguished from all other species of Oxidus by its smaller size (19.3-20.6 mm in length, width of pro- and metazonae 1.5-1.8 mm and 2.1-2.2 $\mathrm{mm}$ ); gonopod coxae more or less stouter and longer than femorite; femorite narrow at base, and strongly expanded towards distal end; gonopod process $h$ hook-like, larger and getting narrower towards pointed tip, spine $z$ small, pointed spiniform; postfemoral lamina $l$ triangularly rounded; mesal lobule not seperated from solenophore tip, which is distinctly emarginated. 


\section{DNA}

COI and 16S barcode data (partial) are deposited in GenBank (Table 1).

\section{Remarks}

This species was originally described by Verhoeff (1940) in the genus Orthomorpha, but was assigned to Oxidus by Jeekel (1963a). The taxonomic position of the species is also well supported by molecular data.

\section{Distribution}

South Japan (Ryukyu Islands).

Oxidus avia (Verhoeff, 1937)

Fig. 8A

Orthomorpha avia Verhoeff, 1937: 33, fig. 1.

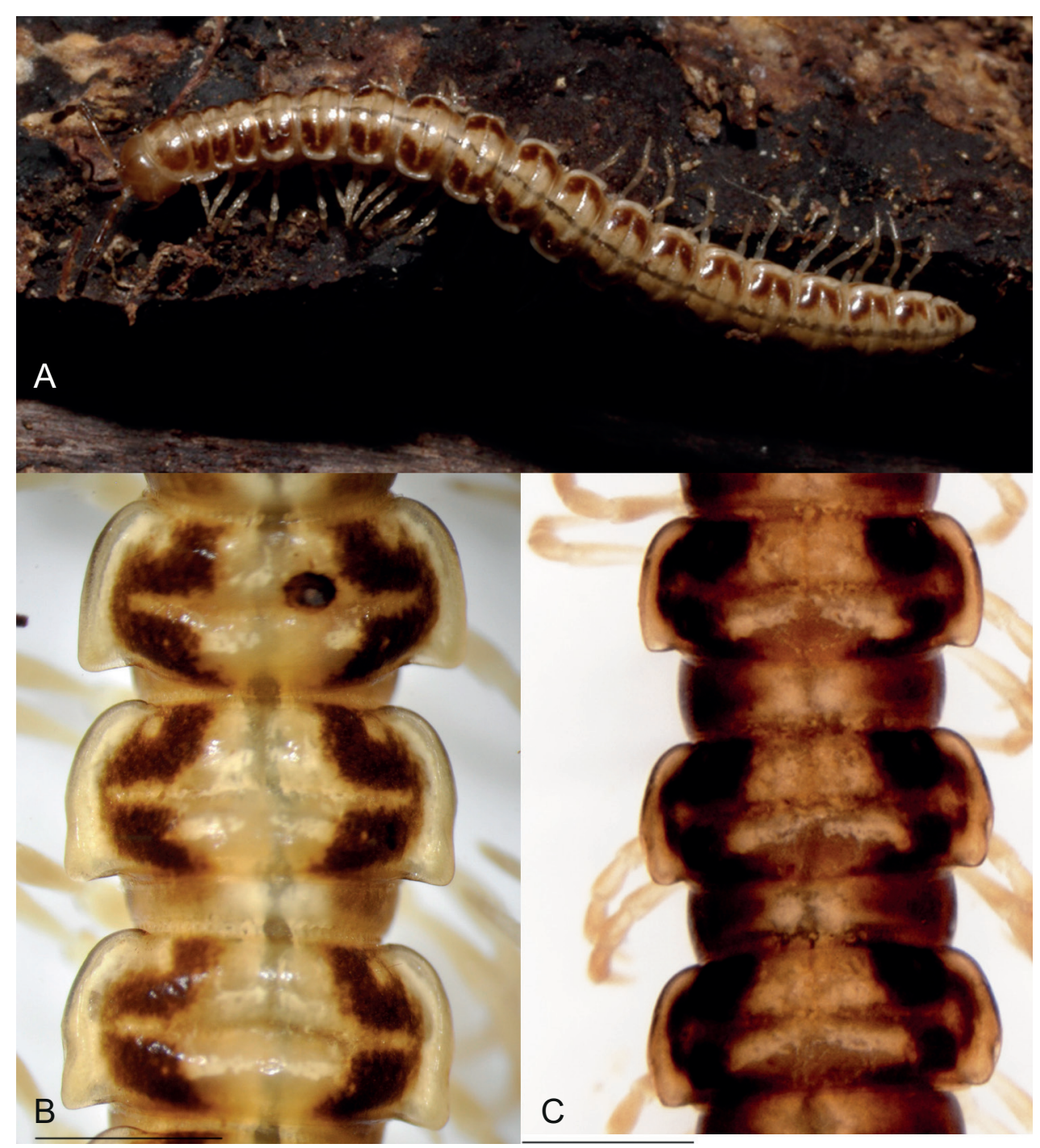

Fig. 5. Oxidus riukiaria (Verhoeff, 1940) from Okinawa, Japan. A. Entire body, length ca $20 \mathrm{~mm}$. B-C.

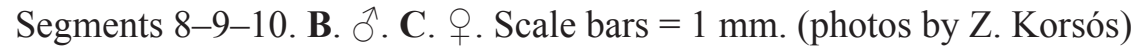



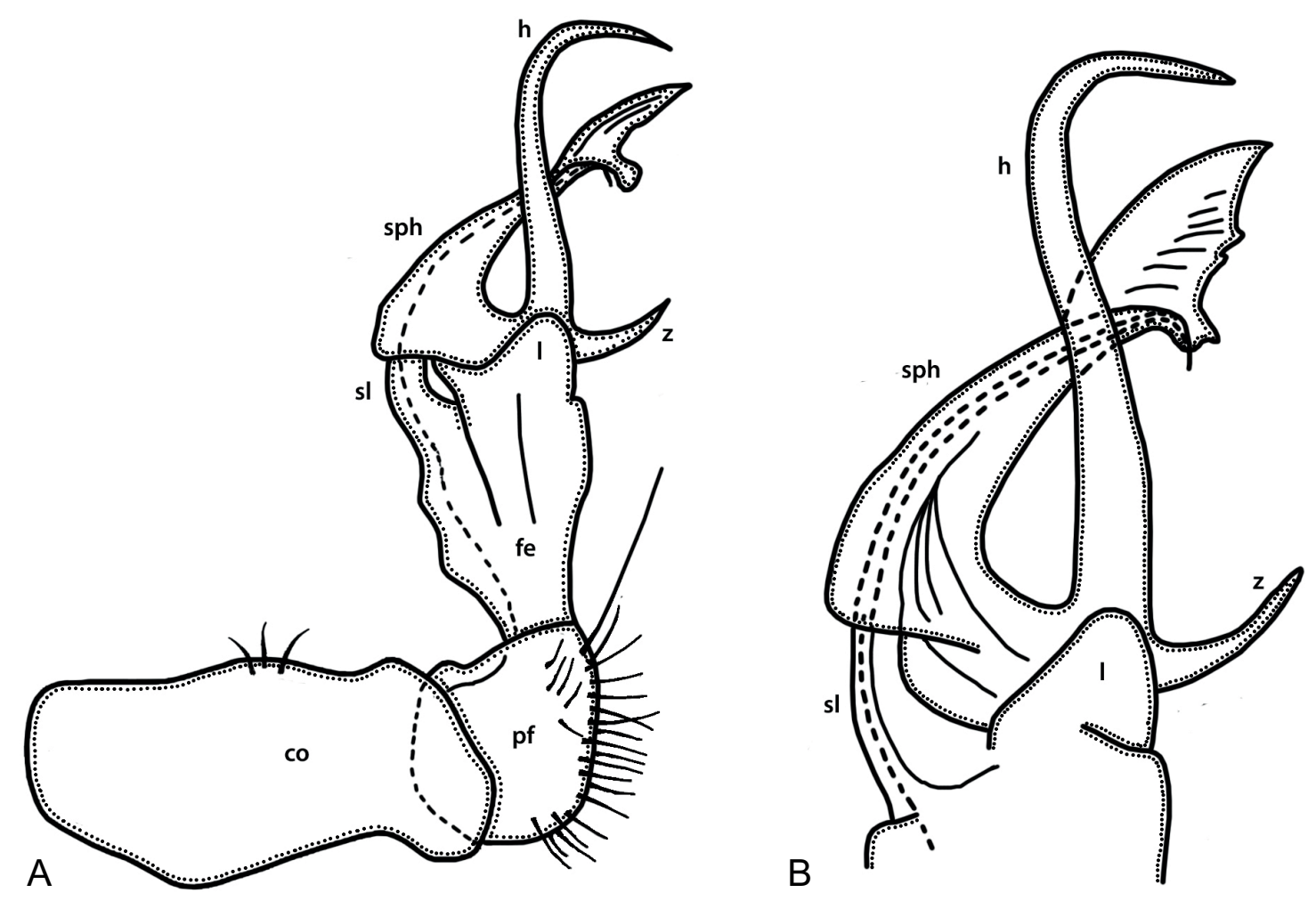

Fig. 6. Left gonopod of Oxidus riukiaria (Verhoeff, 1940). A. Lateral view. B. Postfemoral region, lateral view. Redrawn from Verhoeff 1940. No scale bars.

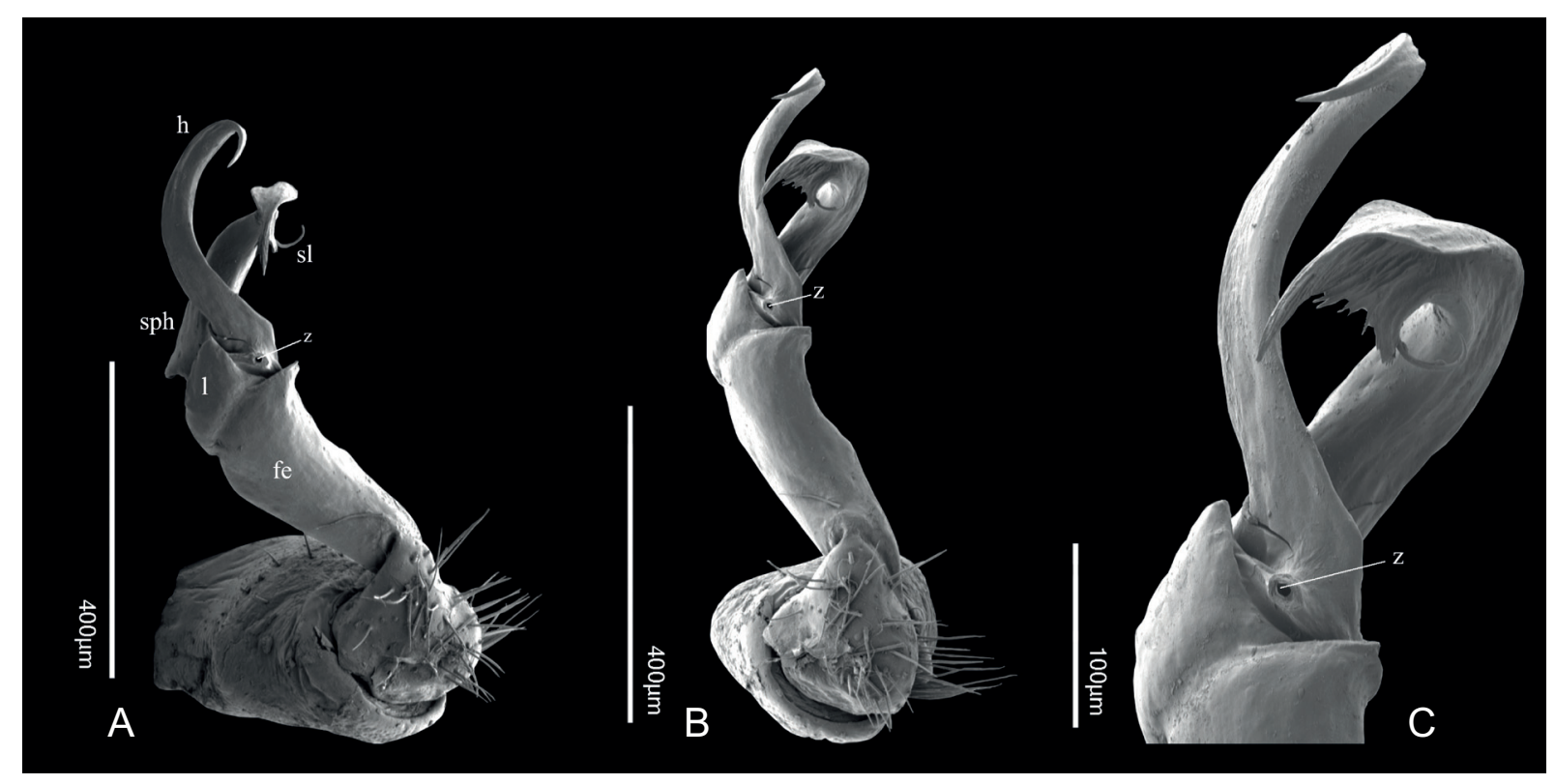

Fig. 7. Left gonopod of Oxidus riukiaria (Verhoeff, 1940), from sample IEBR-H470. A. Lateroventral view. B. Ventral view. C. Postfemoral region, ventral view. Note: $z=$ spine $z$, but broken. 
Oxidus avia - Takakuwa 1954: 38, fig. 33. — Jeekel 1963a: 20. — Nguyen \& Sierwald 2013: 1295.

\section{Diagnosis}

This species can be separated from all other species of Oxidus by its much darker, almost uniformly dark brown body, slender base of gonopod solenophore, more clearly and obtusely emarginated posterior edge of telson; smaller postfemoral lamina $l$; stouter spine $z$; process $h$ more erect, slender and pointed; the base of solenophore less protruded, more strongly rounded; mesal lobule distinctly separated from rounded solenophore tip.

\section{Remarks}

The species was originally described by Verhoeff (1937) under the genus Orthomorpha, then was assigned to the genus Oxidus by Takakuwa (1954).

\section{Distribution}

South Japan (Ryukyu Islands): Ishigaki-jima, Yonaguni-jima; Taiwan.
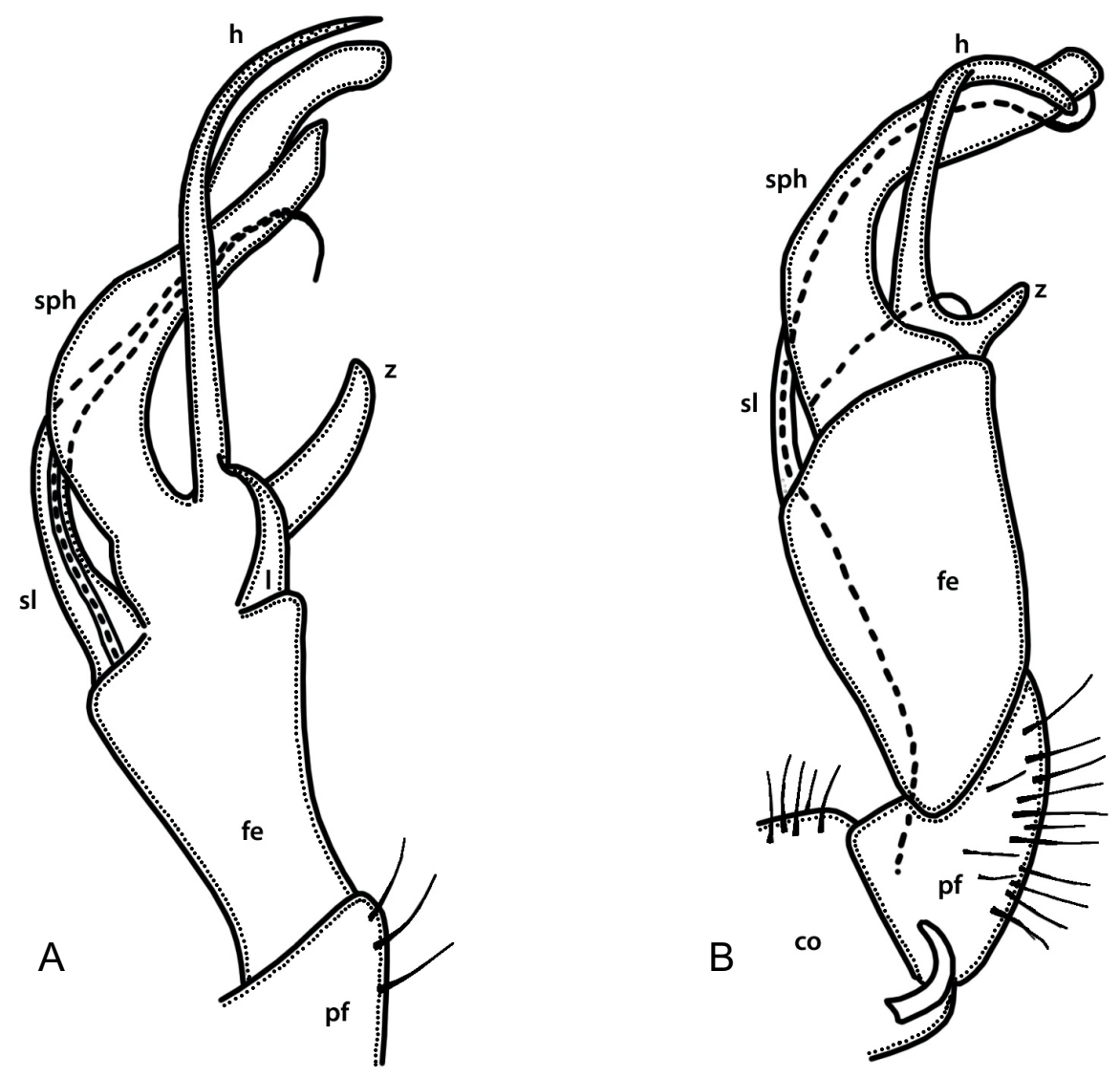

Fig. 8. A. Left gonopod of Oxidus avia (Verhoeff, 1937), lateral view. B. Right gonopod of Oxidus obtusus (Takakuwa, 1942), mesal view. Redrawn from Verhoeff 1937 and Takakuwa 1942a, respectively. No scale bars. 
Oxidus obtusus (Takakuwa, 1942)

Fig. 8B

Orthomorpha obtusa Takakuwa, 1942a: 363, 367, fig. 7.

Oxidus obtusus - Chamberlin \& Wang 1953: 6. — Takakuwa 1954: 37. — Jeekel 1963a: 20. — Nguyen \& Sierwald 2013: 1295.

\section{Diagnosis}

This species can be distinguished by its gonopod femorite being short, very broad gently distad; process $h$ bent upward at tip, like a lamellar sickle; spine $z$ small, obtuse; solenophore large, broad and simple, especially wide at its base; mesal lobule not separated from rounded solenophore tip (Takakuwa 1942a).

\section{Remarks}

This species was described from South Korea (Takakuwa 1942a). Later, Chamberlin \& Wang (1953) reported two $q$ 우 in the collection of the American Natural History Museum (New York) from Japan. It is possible that the locality was mislabelled because they stated that those specimens were collected and deposited by Dr. Takakuwa Y. Thus, it is believed that these two $O+q$ were collected from the same locality as the species holotype (South Korea).

Lim (2001) synonymized $O$. obtusus with $O$. gracilis. He argued that the two species differ only in the number of postfemoral branches, three in O. obtusus and four in O. gracilis; in his opinion, such a difference is minor and cannot be used to separate two species. With the two species $O$. gracilis and O. gigas, those characters are important for species delimitation. It is recommended, therefore, that Oxidus obtusus should be considered a valid species. Examination of further fresh material is needed to confirm that recommendation.

\section{Distribution}

South Korea.

\section{Key to species of the genus Oxidus Cook, 1911}

1. Gonopod femorite stout, more or less cylindrical. Spine $z$ small and short, blunt spiniform

- Gonopod femorite strongly expanded distad, not cylindrical. Spine $z$ long, pointed tuberculiform or spiniform

2. Postfemoral lamina $l$ small, spiniform. Spine $z$ stout, tip more or less rounded, tuberculiform. Base of solenophore slender; mesal lobule clearly separated from rounded tip of solenophore O. avia (Verhoeff, 1937)

- Postfemoral lamina $l$ large, not spiniform. Spine $z$ pointed spiniform. Base of solenophore not slender; tip of solenophore emarginated

3. Postfemoral lamina $l$ triangular. Mesal lobule not separated from solenophore tip

- Postfemoral lamina $l$ not triangular. Mesal lobule clearly separated from solenophore tip

4. Postfemoral lamina $l$ sub-pentagonal. Process $h$ and spine $z$ not separated clearly at base of postfemoral region. Process $h$ pointed

O. gigas (Attems, 1953)

- Postfemoral region $l$ rectangular. Process $h$ and spine $z$ clearly separated at base of postfemoral region. Process $h$ serrated along upper edge O. gracilis (C.L. Koch, 1847) 
Table 2. Average base frequencies of two partial genes COI, 16S rRNA and the 16S-COI combination.

\begin{tabular}{lccccccc}
\hline Genes & \multicolumn{9}{c}{ Average base frequencies } & Length & $\begin{array}{c}\text { Variable } \\
\text { sites }\end{array}$ & $\begin{array}{c}\text { Parsimony } \\
\text { informative } \\
\text { sites }\end{array}$ \\
\hline COI & A & T & G & C & & & 157 \\
16S rRNA & 20.6 & 42.4 & 23.0 & 13.9 & 525 & 177 & 161 \\
16S-COI combination & 31.9 & 35.7 & 24.0 & 8.4 & 466 & 199 & 297 \\
\hline
\end{tabular}

\section{Molecular phylogeny of the genus Oxidus Cook, 1911}

\section{DNA variations and distances}

The aligned dataset for COI consisted of $525 \mathrm{bp}$ sequences. The nucleotide frequencies for $\mathrm{A}, \mathrm{T}$, $\mathrm{G}$, and $\mathrm{C}$ were $20.6 \%, 42.4 \%, 23.0 \%$, and $13.9 \%$, respectively. The GC content was $37 \%$. The COI dataset contained 157 (29.9\%) parsimony informative and 177 (33.7\%) variable sites (see Table 2). The uncorrected $\mathrm{p}$-distance between taxa ranged from 0.000 to 0.192 . The overall $\mathrm{p}$-distance was 0.146 .

The aligned dataset for the 16S rRNA gene contained $466 \mathrm{bp}$ sequences. The nucleotide frequencies of $\mathrm{A}, \mathrm{T}, \mathrm{G}$, and $\mathrm{C}$ were $31.9 \%, 35.7 \%, 24.0 \%$, and $8.4 \%$, respectively. The GC content was $32.4 \%$. The 16S rRNA dataset contained 161 (14.7\%) parsimony informative and 199 (34.7\%) variable sites (see Table 2). The uncorrected p-distance between the taxa ranged from 0.000 to 0.279 . The overall p-distance was 0.169 .

The aligned dataset for the combination of the 16S rRNA and COI genes contained $991 \mathrm{bp}$ sequences. The nucleotide frequencies of $\mathrm{A}, \mathrm{T}, \mathrm{G}$, and $\mathrm{C}$ were $26.0 \%, 39.1 \%, 23.3 \%$, and $11.6 \%$, respectively. The GC content was 34.9\%. This combined dataset contained 297 (30.0\%) parsimony informative and 367 $(37.0 \%)$ variable sites (see Table 2). The uncorrected p-distance between the taxa ranged from 0.000 to 0.229 . The overall p-distance was 0.157 (Table 3). Within the genus Oxidus, the three species compared had significant genetic distances: $0.106-0.113$ between $O$. gigas and $O$. gracilis; $0.119-0.128$ between $O$. gigas and $O$. riukiaria; and 0.103-0.106 between $O$. gracilis and $O$. riukiaria. The genetic distance between species of Oxidus and other genera ranged from 0.162 (between O. riukiaria and Tylopus roseiparaterga) to 0.229 (between $O$. gigas and Kronopolites sp.).

\section{Phylogenetic analyses}

Phylogenetic trees were reconstructed for the COI and 16S-COI combination using ML and BI. For ML-analysis, we considered clades with bootstrap values below $65 \%$, between 65 and $89 \%$, or more than $89 \%$ to be weakly supported, moderately supported, or strongly supported, respectively (Pimvichai et al. 2014). For BI-analysis, clades with a BI posterior probability less than $0.7 \mathrm{bpp}$, between 0.7 and $0.95 \mathrm{bpp}$, or more than $0.95 \mathrm{bpp}$ are considered to be weakly supported, moderately supported, or strongly supported, respectively.

Based on a Bayesian Inference and Maximum Likelihood analysis of a 525 bp fragment of COI from 18 taxa, a phylogenetic tree was reconstructed (Fig. 9). The genus Oxidus formed a monophyletic clade. It was separated from its sister group (genus Tylopus) with an ML bootstrap value of $<65 \%$ and a BI posterior probability of $0.76 \mathrm{bpp}$. Sellanucheza is considered as the sister group of Tylopus plus Oxidus. The separation of Sellanucheza and (Tylopus plus Oxidus) is supported with an ML bootstrap value of $<65 \%$ and a BI posterior probability of $0.98 \mathrm{bpp}$. Within Oxidus, the three species formed three clearly distinguished clades. However, O. gigas was more closely related to $O$. gracilis, with an ML bootstrap value of $74 \%$ and a BI posterior probability of $0.86 \mathrm{bpp}$. O. riukiaria was separated from the group of 
Table 3. Uncorrected distance of the combination of COI and 16S rRNA genes calculated by MEGA 6.0. The genetic distances among species of Oxidus are highlighted in bold.

\begin{tabular}{|c|c|c|c|c|c|c|c|c|c|c|c|c|}
\hline & $\begin{array}{l}\text { Species / } \\
\text { p-distance }\end{array}$ & 1 & 2 & 3 & 4 & 5 & 6 & 7 & 8 & 9 & 10 & 11 \\
\hline 1 & $\begin{array}{l}\text { Tonkinosoma } \\
\text { jeekeli (545) }\end{array}$ & & & & & & & & & & & \\
\hline 2 & $\begin{array}{l}\text { Kronopolites } \\
\text { montanus (175) }\end{array}$ & 0.196 & & & & & & & & & & \\
\hline 3 & $\begin{array}{l}\text { Kronopolites sp. } \\
\text { (IPE4) }\end{array}$ & 0.196 & 0.010 & & & & & & & & & \\
\hline 4 & $\begin{array}{l}\text { Tylopus crassipes } \\
(92)\end{array}$ & 0.201 & 0.225 & 0.220 & & & & & & & & \\
\hline 5 & $\begin{array}{l}\text { Tylopus } \\
\text { roseiparaterga } \\
\text { (185A) }\end{array}$ & 0.205 & 0.207 & 0.203 & 0.119 & & & & & & & \\
\hline 6 & Oxidus gigas (516) & 0.201 & 0.225 & 0.229 & 0.163 & 0.186 & & & & & & \\
\hline 7 & Oxidus gigas (133) & 0.203 & 0.224 & 0.223 & 0.172 & 0.187 & 0.040 & & & & & \\
\hline 8 & $\begin{array}{l}\text { Oxidus gracilis } \\
(466)\end{array}$ & 0.188 & 0.205 & 0.201 & 0.166 & 0.172 & 0.113 & 0.108 & & & & \\
\hline 9 & $\begin{array}{l}\text { Oxidus gracilis } \\
\text { (471) }\end{array}$ & 0.190 & 0.205 & 0.201 & 0.169 & 0.172 & 0.113 & 0.106 & 0.002 & & & \\
\hline 10 & $\begin{array}{l}\text { Oxidus gracilis } \\
\text { (USA) }\end{array}$ & 0.188 & 0.205 & 0.201 & 0.166 & 0.172 & 0.113 & 0.108 & 0.000 & 0.002 & & \\
\hline 11 & $\begin{array}{l}\text { Oxidus riukiaria } \\
(500)\end{array}$ & 0.186 & 0.208 & 0.208 & 0.166 & 0.170 & 0.128 & 0.125 & 0.106 & 0.104 & 0.106 & \\
\hline 12 & $\begin{array}{l}\text { Oxidus riukiaria } \\
(500 \mathrm{~J})\end{array}$ & 0.186 & 0.204 & 0.206 & 0.169 & 0.162 & 0.128 & 0.119 & 0.104 & 0.103 & 0.104 & 0.037 \\
\hline
\end{tabular}

O. gigas and O. gracilis with a well supported ML bootstrap value of $98 \%$ and a BI posterior probability of $1.00 \mathrm{bpp}$.

Based on BI and ML analysis of the $991 \mathrm{bp}$ combination of the genes 16S rRNA and COI, a phylogenetic tree of 12 taxa was constructed (Fig. 10). As in the COI tree, the genus Oxidus formed a monophylic clade clearly separated from species of Tylopus, with a well supported ML bootstrap value of $100 \%$ and a BI posterior probability of $1.00 \mathrm{bpp}$. The three Oxidus species were also separated from each other. O. riukiaria formed a sister group with $O$. gigas plus O. gracilis, with an ML bootstrap value of $100 \%$ and a BI posterior probability of $1.00 \mathrm{bpp}$. The species $O$. gigas was separated from $O$. gracilis with a moderately supported ML bootstrap value of $83 \%$ and a BI posterior probability of $0.91 \mathrm{bpp}$.

\section{Discussion}

Both phylogenic trees showed the monophyly of each Oxidus species (Figs 9-10). In other words, all three species are distinctly separated from each other (genetic distances: $0.106-0.113$ between $O$. gigas and $O$. gracilis; $0.119-0.128$ between $O$. gigas and $O$. riukiaria; and $0.103-0.106$ between $O$. gracilis and $O$. riukiaria). The species $O$. gigas was originally proposed as a subspecies of $O$. gracilis (Attems, 1953). After being raised to full species rank, it is still closer to O. gracilis than to other species of Oxidus. This relationship is well supported by a monophyletic clade of the two species, O. gracilis and $O$. gigas. The other species, $O$. riukiaria, is considered as the sister species of $O$. gracilis plus $O$. gigas. 
The genus Oxidus is placed in the Sulciferini with the typical characters of a spiral solenophore completely sheathing the solenomere, presence of postfemoral demarcation, and postfemoral processes (Jeekel 1968). Until now, no relationship analysis among sulciferine genera has been reported, except that Golovatch \& Enghoff (1993) have reported a close relationship among species of Tylopus and Oxidus gracilis. These authors recommended that Oxidus gracilis or the genus Oxidus should be considered as the sister of genus Tylopus because both genera have similar gonopod characters, such as the presence of lamina $l$, process $h$, and spine $z$. Molecular analysis based on the COI gene and the combination of 16S and COI genes provides good supports for the recommendation of Golovatch \& Enghoff (1993). In both phylogenetic trees, Oxidus and Tylopus formed a group with well supported bootstrap value and BI posterior probability (Figs 9-10).

The genus Sellanucheza Enghoff, Golovatch \& Nguyen, 2004 was originally assigned to the tribe Tonkinosomatini (Enghoff et al. 2004). However, Golovatch (2013) suggested that it was better to place this genus in the tribe Sulciferini. His suggestion is well supported by the molecular data obtained from this study. The genus Sellanucheza is relatively close to the group of Tylopus + Oxidus, with a very high BI value (0.98 bpp) in the phylogenetic tree inferred from the $525 \mathrm{bp}$ fragment of the COI gene (Fig. 10).

\section{Conclusion}

The genus Oxidus Cook, 1911 consists of five species, O. avia, O. gigas, O. gracilis, O. riukiaria, and a doubtful species, $O$. obtusus. While $O$. gracilis is a cosmopolitan species, widely found in temperate and sub-tropical regions over the world, the other species have limited distributions in particular regions: O. gigas in northern Vietnam, and O. riukiaria and O. avia in the Ryukyu Islands (Japan).

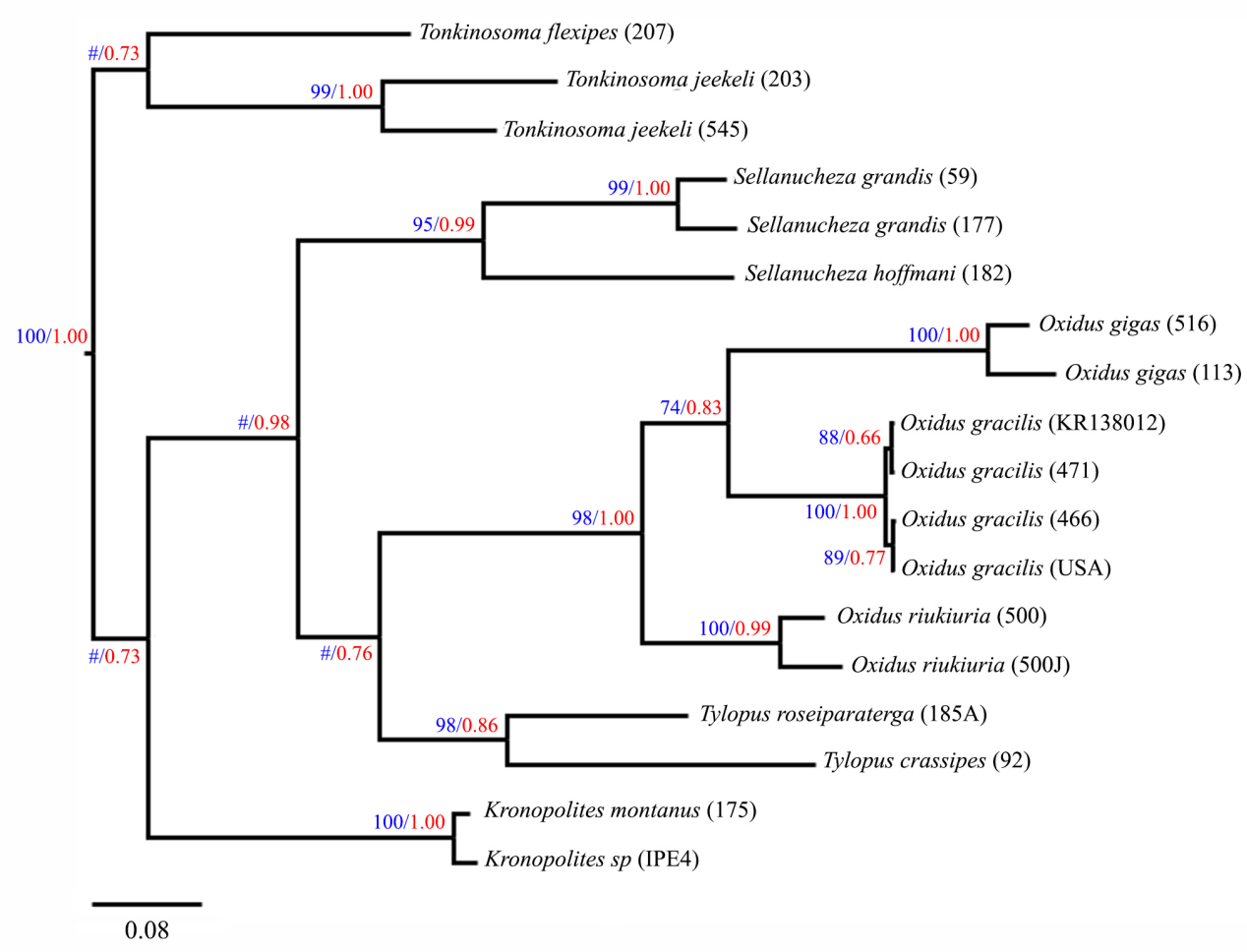

Fig. 9. Phylogenetic tree of the genus Oxidus and some closely related groups based on Maximum Likelihood and Bayesian Inference Analysis of a 525 bp fragment of the COI gene (\# = a value less than $65 \%)$. 
Oxidus is a monophyletic genus, and most closely related to the genus Tylopus based on the molecular analysis. All three species, $O$. gigas, $O$. gracilis and $O$. riukiaria, are distinctly separated and $O$. gigas is closer to $O$. gracilis than to $O$. riukiaria.

\section{Acknowledgements}

The authors thank the National Science Foundation of Korea for their support through the postdoctoral fellowship awarded to A.D. Nguyen, and Dr. Hsueh-Wen Chang (Sun Yat-Sen National University, Taiwan) for his kindly providing specimens of Oxidus gracilis. The second author would like to express his sincere gratitude to Prof. H. Ota and M. Toda (Tropical Biosphere Research Center, University of the Ryukyus, Okinawa) for inviting him to study millipedes in the Ryukyus. Two anonymous reviewers are acknowledged for their invaluable comments and suggestions to improve the paper.

This research is funded by the Vietnam National Foundation for Science and Technology Development (NAFOSTED) under grant number 106-NN.05-2015.22 to A.D. Nguyen, and the National Research Foundation of Korea (NRF), Ministry of Science, ICT \& Future Planning under grant NRF2012R1A2A2A01046531 to U.W. Hwang.

\section{References}

Altschul S.F., Madden T.L., Schäffer A.A., Zhang J., Zhang Z., Miller W. \& Lipman D.J. 1997. Gapped BLAST and PSI-BLAST: a new generation of protein database search programs. Nucleic Acids Research 25: 3389-3402.

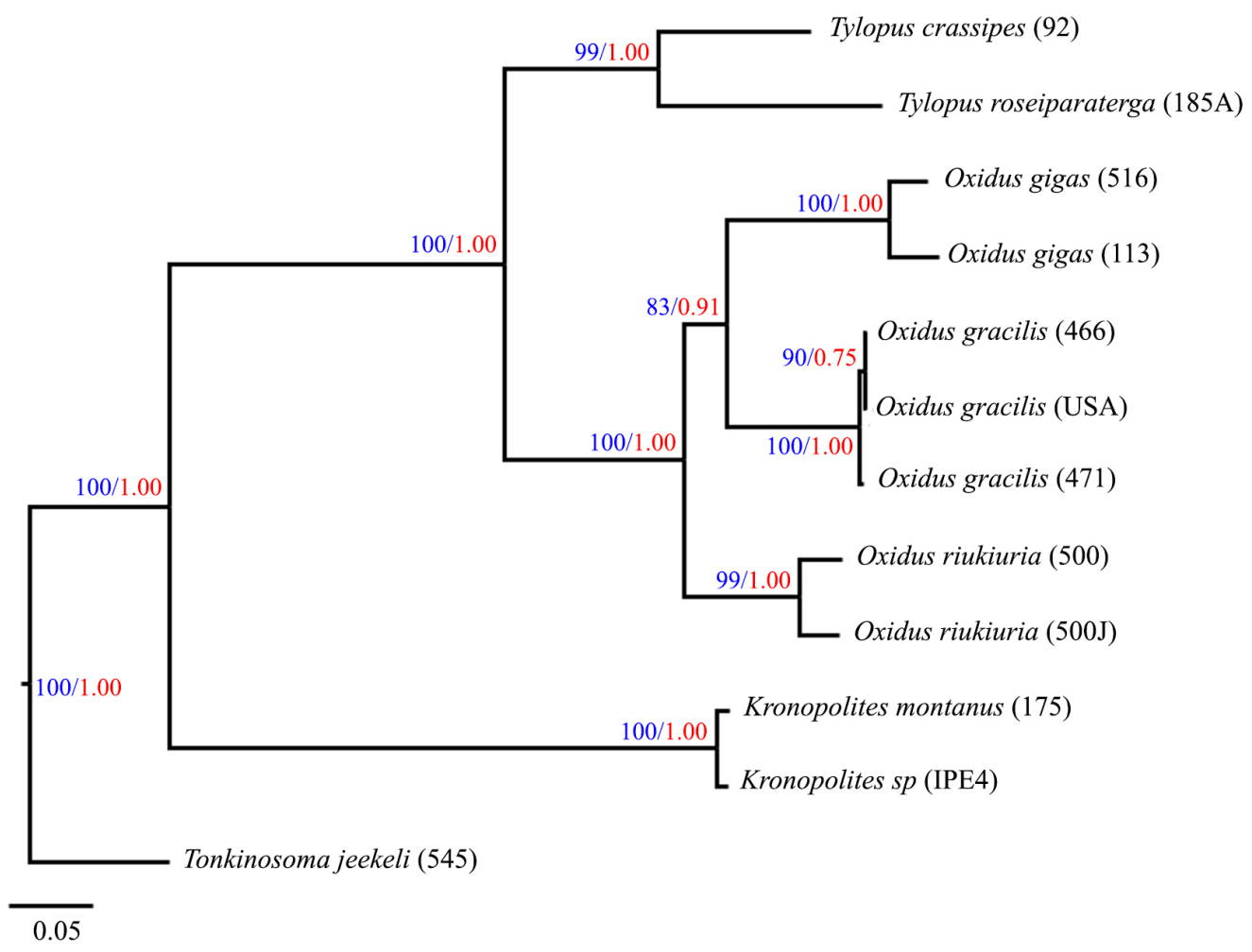

Fig. 10. Phylogenetic tree of the genus Oxidus and some closely related groups based on Maximum Likelihood and Bayesian Inference Analysis of a $991 \mathrm{bp}$ fragment of the combination of 16S rRNA and COI genes. 
Attems C. 1914. Die indo-australischen Myriopoden. Archiv für Naturgeschichte 80A (4): 1-398.

Attems C. 1953. Myriopoden von Indochina: Expedition von C. Dawydoff (1938-1939). Mémoires du Muséum national d'Histoire naturelle, Série A - Zoologie 5 (3), Muséum national d'Histoire naturelle, Paris.

Bollman C.H. 1893. The Myriapoda of North America. Bulletin of the United States National Museum 46: $1-210$.

Brölemann H.W. 1916. Essai de classification des Polydesmiens [Myriapodes]. Annales de la Société entomologique de France 84: 523-608. Available from http://biodiversitylibrary.org/page/8559505 [accessed 6 Jan. 2017].

Chamberlin R.V. 1945. On some diplopods from the Indo-Australian Archipelago. American Museum Novitates 1282: 1-43.

Chamberlin R.V. \& Wang Y.M. 1953. Records of millipeds (Diplopoda) from Japan and other Oriental areas, with descriptions of new genera and species. American Museum Novitates 1621: 1-13.

Chen C.-C., Golovatch S.I. \& Chang H.-W. 2006. The millipede tribe Sulciferini in Taiwan (Diplopoda: Polydesmida: Paradoxosomatidae). Norwegian Journal of Entomology 53 (2): 253-255.

Cook O.F. 1911. The hothouse milliped as a new genus. Proceedings of the United States National Museum 40(1842): 625-631.

Edgar R.C. 2004. MUSCLE: multiple sequence alignment with high accuracy and high throughput. Nucleic Acids Research 32 (5): 1792-1797. https://doi.org/10.1093/nar/gkh340

Enghoff H., Golovatch S.I. \& Nguyen D.A. 2004. A review of the millipede fauna of Vietnam (Diplopoda). Arthropoda Selecta 13 (1/2): 29-43.

Folmer O., Black M., Hoeh W., Lutz R. \& Vrijenhoek R. 1994. DNA primers for amplification of mitochondrial cytochrome $\mathrm{c}$ oxidase subunit I from diverse metazoan invertebrates. Molecular Marine Biology and Biotechnology 3: 294-299.

Golovatch S.I. 1983. Millipedes (Diplopoda) of the fauna of Vietnam. In: Sokolov V.E. (ed.) Fauna and Ecology of the Animals of Vietnam: 178-186. "Nauka" Publishing, Moscow.

Golovatch S.I. 1984. Contribution to the millipede fauna of Vietnam (Diplopoda), II. Acta Zoologica Hungarica 30 (1-2): 53-77.

Golovatch S.I. 2013. On several new or poorly-known Oriental Paradoxosomatidae (Diplopoda: Polydesmida), XIII. Arthropoda Selecta 22 (1): 1-31.

Golovatch S.I. \& Enghoff H. 1993. Review of the genus Tylopus, with descriptions of new species from Thailand (Diplopoda, Polydesmida, Paradoxosomatidae). Steenstrupia 19 (3): 85-125.

Hall T.A. 1999. BioEdit: a user-friendly biological sequence alignment editor and analysis program for Windows 95/98/NT. Nucleic Acids Symposium Series 41: 95-98.

Hasegawa M., Kishino H. \& Yano T. 1985. Dating of the human-ape splitting by a molecular clock of mitochondrial DNA. Journal of Molecular Evolution 22 (2): 160-174. https://doi.org/10.1007/ $\underline{\mathrm{BF} 02101694}$

Hoffman R.L. 1963. A contribution to the knowledge of Asiatic strongylosomoid Diplopoda (Polydesmida: Strongylosomatidae). The Annals and Magazine of Natural History, Series 135 (58): 577-593. https://doi.org/10.1080/00222936208651289

Huelsenbeck J.P. \& Bollback J.P. 2001. Empirical and hierarchical Bayesian estimation of ancestral states. Systematic Biology 50: 351-366. http://www.jstor.org/stable/3070928 
Jeekel C.A.W. 1963a. Diplopoda of Guiana. Studies on the Fauna of Suriname and other Guyanas 4 (11): $1-157$.

Jeekel C.A.W. 1963b. Paradoxosomatidae from Borneo (Diplopoda, Polydesmida). Tijdschrift voor Entomologie 106 (6): 205-283.

Jeekel C.A.W. 1968. On the Classification and Geographical Distribution of the Family Paradoxosomatidae (Diplopoda, Polydesmida). PhD Thesis, University of Amsterdam, The Netherlands.

Jeekel C.A.W. 1988. The generic position of Orthomorpha bucharensis Lohmander and O. muminabadensis Gulička, and the taxonomic status of Hedinomorpha Verhoff (Diplopoda, Polydesmida, Paradoxosomatidae). Bulletin Zoölogisch Museum, Universiteit van Amsterdam 11 (11): 97-104.

Koch C.L. 1847. System der Myriapoden mit den Verzeichnissen und Berichtigungen zu Deutschlands Crustaceen, Myriapoden und Arachniden. In: Panzer G.W.F. \& Herrich-Schäffer A. (eds) Kritische Revision der Insectenfauna Deutschlands, III: 1-196. Bändchen, Regensburg.

Koch C.L. 1863. Die Myriapoden 2. Getreu nach der Natur abgebildet und beschrieben. Druck und Verlag von H.W. Schmidt, Halle.

Likhitrakarn N., Golovatch S.I., Prateepasen R. \& Panha S. 2010. Review of the genus Tylopus Jeekel, 1968, with descriptions of five new species from Thailand (Diplopoda, Polydesmida, Paradoxosomatidae). ZooKeys 72: 23-68. https://doi.org/10.3897/zookeys.72.744

Lim K.Y. 2001. Taxonomy of Millipedes (Arthropoda: Diplopoda) in Korea. PhD dissertation, Chonbuk National University, Jeonju, Korea.

Miyosi Y. 1959. Über japanische Diplopoden. Special Number, Arachnological Society of East Asia, Osaka.

Nguyen A.D. \& Sierwald P. 2013. A worldwide catalog of the family Paradoxosomatidae Daday, 1889 (Diplopoda: Polydesmida). CheckList 9: 1132-1353.

Pimvichai P., Enghoff H. \& Panha S. 2014. Molecular phylogeny of the Thyropygus allevatus group of giant millipedes and some closely related groups. Molecular Phylogenetics and Evolution 71: 170-183. https://doi.org/10.1016/j.ympev.2013.11.006

Takakuwa Y. 1942a. Die Myriopoden aus Formosa, Philippinien u.s.w. Transactions of the Natural History Society of Formosa 32 (231): 359-367.

Takakuwa Y. 1942b Die Orthomorpha-Arten aus Japan. Transactions of the Natural History Society of Formosa 32 (224): 44-47.

Takakuwa Y. 1954. Diplopoden aus Japan und ihn angrenzenden Gebieten. Japan Society for the Promotion of Science, Tokyo.

Tamura K. \& Nei M. 1993. Estimation of the number of nucleotide substitutions in the control region of mitochondrial DNA in humans and chimpanzees. Molecular Biology and Evolution 10 (3): 512-526.

Tamura K., Stecher G., Peterson D., Filipski A. \& Kumar S. 2013. MEGA6: Molecular Evolutionary Genetics Analysis version 6.0. Molecular Biology and Evolution 30: 2725-2729.

Verhoeff K.W. 1937. Zur Kenntnis ostasiatischer Diplopoden. II. Zoologischer Anzeiger 119 (1/2): 3340 .

Verhoeff K.W. 1940. Zur Kenntnis ostasiatischer Diplopoden. V (Polydesmoidea). Zoologischer Anzeiger 131 (5/6): 129-145. 
Wang Y.M. 1957. Serica 1g: Records of myriapods on Taiwan Islands (4). Six new polydesmids. Quarterly Journal of the Taiwan Museum 10 (3/4): 103-111.

Manuscript received: 26 May 2016

Manuscript accepted: 5 July 2016

Published on: 7 March 2017

Topic editor: Rudy Jocqué

Desk editor: Laurence Bénichou

Printed versions of all papers are also deposited in the libraries of the institutes that are members of the EJT consortium: Muséum national d'Histoire naturelle, Paris, France; Botanic Garden Meise, Belgium; Royal Museum for Central Africa, Tervuren, Belgium; Natural History Museum, London, United Kingdom; Royal Belgian Institute of Natural Sciences, Brussels, Belgium; Natural History Museum of Denmark, Copenhagen, Denmark; Naturalis Biodiversity Center, Leiden, the Netherlands. 